\title{
Palaeoclimatic event at the Lochkovian-Pragian boundary recorded in magnetic susceptibility and gamma-ray spectrometry (Prague Synclinorium, Czech Republic)
}

\author{
FRANTIŠEK VACEK
}

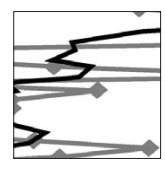

\begin{abstract}
The MS and GRS stratigraphic records of three Lochkovian-Pragian boundary sections representing different depositional conditions have been evaluated. All studied sections are characterized by increased MS magnitudes from Lochkovian to Pragian. Another prominent characteristic is a turnover in the Th/U ratio; the Pragian magnitudes are usually 2-4 times higher than the Lochkovian ones. Based on a combined physical stratigraphic and sedimentological approach a previously reported regressive event at this time interval is ascribed to climate warming accompanied by enhanced carbonate productivity while eustatic sea-level changes probably played only a minor role, which was locally also combined with synsedimentary uplift. - Key words: Devonian, Lochkovian-Pragian boundary, Prague Synclinorium, magnetic susceptibility, gamma-ray spectrometry.
\end{abstract}

\begin{abstract}
VACEK, F. 2011. Palaeoclimatic event at the Lochkovian-Pragian boundary recorded in magnetic susceptibility and gamma-ray spectrometry (Prague Synclinorium, Czech Republic). Bulletin of Geosciences 86(2), 259-268 (4 figures, 1 table). Czech Geological Survey, Prague. ISSN 1214-1119. Manuscript received November 9, 2010; accepted in revised form March 15, 2011; published online May 6, 2011; issued June 20, 2011.
\end{abstract}

František Vacek, School of Geography, Earth \& Environmental Sciences, University of Birmingham, Aston Webb A Block, Edgbaston, Birmingham B15 2TT, United Kingdom; f.vacek@bham.ac.uk

Physical stratigraphic methods (magnetic susceptibility and gamma-ray spectrometry) have been applied worldwide during last fifteen years in various areas and stratigraphic levels. In the Czech Republic this approach has been used mainly in the Devonian of the Prague Synclinorium (central Bohemia; e.g., Slavík et al. 2000; Crick et al. 1997, 2001; Ellwood et al. 2006; Hladil et al. 2010b; Koptíková 2010; Koptíková et al. 2010a, b; Vacek 2010; Vacek et al. 2010) and Moravosilezian Zone (Moravia; e.g., Hladil 2002; Hladil et al. 2000, 2003a, b, 2006, 2009; Geršl \& Hladil 2004; Bábek et al. 2007; Boulvain et al. 2010). Physical stratigraphic methods have been used for intrabasinal or interregional correlations as well as auxiliary data for characteristics of depositional environments and their evolution, especially in cooperation with sedimentologists and biostratigraphers.

The Prague Synclinorium is a classical area for Devonian System, where several stages have been defined with type sections (Global Boundary Stratotype Section and Point, GSSP). The Pragian Stage was defined by Chlupác $(1981,1982)$; its base has been first established at the base of Eognathodus sulcatus sulcatus conodont zone at Černá rokle near Kosoř (Weddige 1987). This selection was rede- fined in 1989 by decision of Subcommission on Devonian Stratigraphy by approval of the Homolka section at PrahaVelká Chuchle as a new GSSP (Chlupáč \& Oliver 1989). However, the status of the Pragian Stage has been broadly discussed recently because after the definition of the Pragian-Emsian boundary at Zinzilban Gorge (Uzbekistan) the major part of classical Pragian now correlates with the Emsian (for more details see Slavík et al. 2007, Carls et al. 2008). Thus, it is necessary to study the type sections by various methods to improve and support their correlation potential for further regional and interregional correlations. Intensive work has been done mainly in conodont stratigraphy (Slavík \& Hladil 2004, Slavík et al. 2007), but it is also important to support biostratigraphic data by other methods, e.g. magnetic susceptibility (MS) and gamma-spectrometric (GRS) stratigraphy or chemostratigraphy. In this particular level several papers have been published dealing with, e.g. carbon and oxygen isotopes stratigraphy (Hladíková et al. 1997, Gessa \& Lécuyer 1998, Buggisch \& Mann 2004) or the MS and GRS stratigraphy (Slavík et al. 2000; Koptíková et al. 2010a, b; Vacek 2010).

Results of studies on the MS and GRS stratigraphy of three type sections, including the Lochkovian-Pragian 


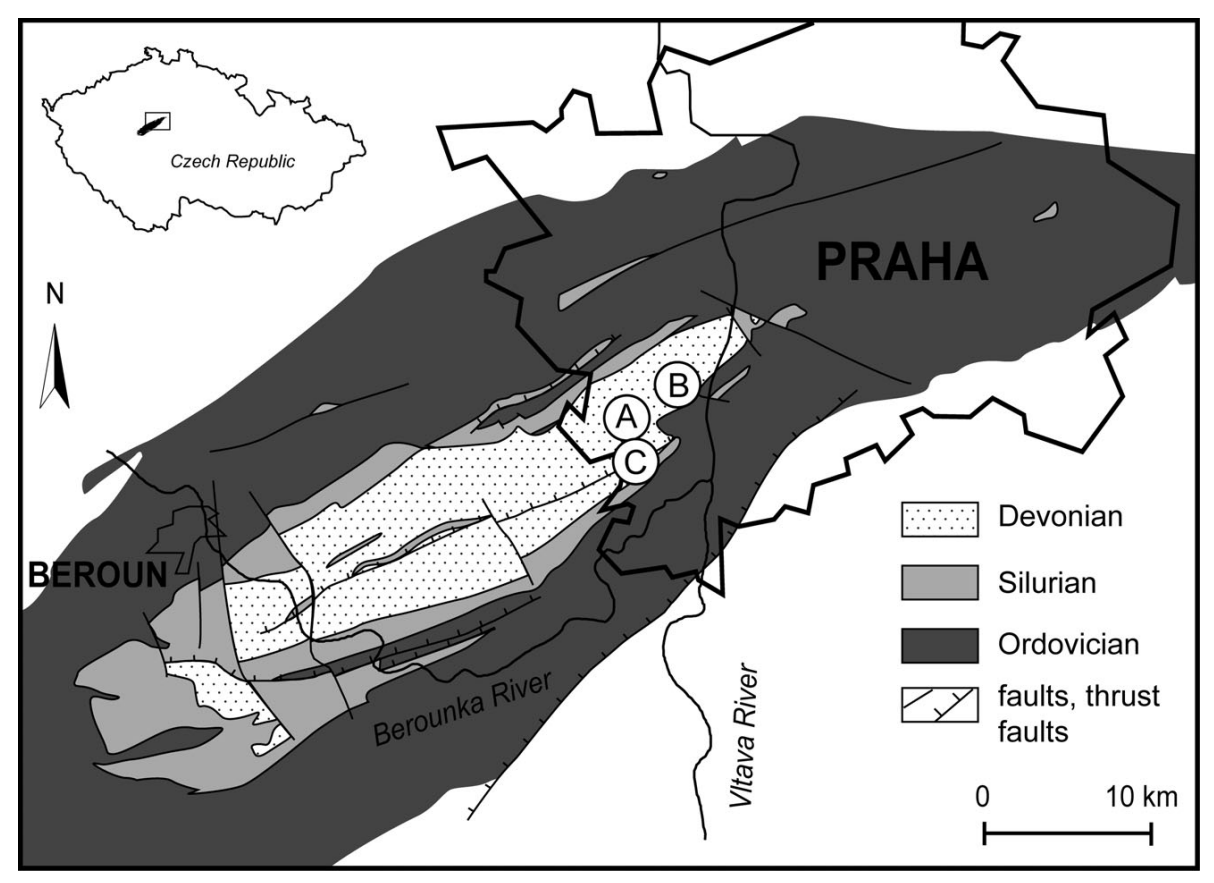

Figure 1. Simplified geological map of the central part of the Prague Synclinorium with position of the studied sections. • A - Cikánka near Praha-Slivenec; B - Homolka near Praha-Velká Chuchle; $\mathrm{C}$ - Černá rokle near Kosoř.
GSSP at Homolka, Praha-Velká Chuchle, are reported in this paper. These results can be used within the Prague Synclinorium (our studied sections and other published data) but may prove useful in interregional correlations as well.

\section{Geological setting}

The Prague Synclinorium occupies the central part of the Teplá-Barrandian Zone (Fig. 1). This unit consists of Neoproterozoic to Middle Devonian sedimentary and volcanic sequences, which were deformed and locally metamorphosed during Cadomian and Variscan orogenies (Hajná et al. 2010). The Devonian sequences in the Prague Synclinorium are characterized by the predominance of carbonates and a lack of major hiatuses (except for the Koněprusy area, $\mathrm{S}$ of Beroun; for more details see Chlupáč et al. 1998). Palaeogeographic and palaeomagnetic interpretations place the Prague Synclinorium to the northern margins of Gondwana with close relationship to Armorica (Krs \& Pruner 1995, Krs et al. 2001, Patočka et al. 2003).

The classical Pragian (sensu Chlupáč 1981, 1982) approximately corresponds to the Praha Formation (Fm.). The Lochkovian-Pragian (L-P) boundary is close to the upper contact of the Lochkov Formation (approximately corresponding to Lochkovian) with the Praha Formation. Facies development of both formations is characterized by lateral transitions from bioclastic limestone facies in the NW/SW part of the synclinorium to fine-grained limestone/shale facies in the SE. Two contrasting facies are distinguished in the Lochkov Fm. - Kotýs and Radotín Limestone (Chlupáč 1953, 1981). The Kotýs Limestone (Lm.) represents relatively shallow-water deposits of the lower subtidal in contact with storm-wave base (Vacek 2007), whereas the Radotín Lm. was deposited as fine-grained distal calciturbidites on the carbonate slope (Vorel 2006, Vacek 2007).

The Praha Fm. exhibits the most diversified facies of any Devonian unit in the Prague Synclinorium - it includes several members representing the transition from shallow-water carbonates (Koněprusy, Slivenec Lm.) to hemipelagic mudstones (Dvorce-Prokop Lm.; Velebilová \& Šarf 1996). In the traditional facies schemes of Chlupáč $(1957,1982)$ there are several transitional facies types (Loděnice, Reporyje Lm.) between these two contrasting settings. Shallow-water facies have maximum extent in the lower part of the formation, which reflects the regressive Lochkovian-Pragian boundary event (Chlupáč \& Kukal 1988). The overlying sequence reflects gradual deepening and expansion of areas with pelagic facies. These contrasting facies should gradually pass into each other both vertically and laterally. However, Melichar \& Hladil (1999) or Melichar (2004) proposed a complicated structural model of the Prague Synclinorium that presumes significant convergence of facies representing a more extensive sedimentary system.

The L-P boundary was defined at the base of Eognathodus sulcatus sulcatus Zone at Černá rokle near Kosoř. However, this decision was revised later and a new GSSP at Homolka near Praha-Velká Chuchle was approved by decision of the Subcommission on Devonian Stratigraphy and IUGS at the International Geological Congress in Washington, 1989 (Chlupáč \& Oliver 1989). This definition is based on the conodont studies carried out by Weddige (in Chlupáč et al. 1985, Weddige 1987). However, his results were revised subsequently by Slavík \& 
Cikánka Quarry at Praha-Slivenec

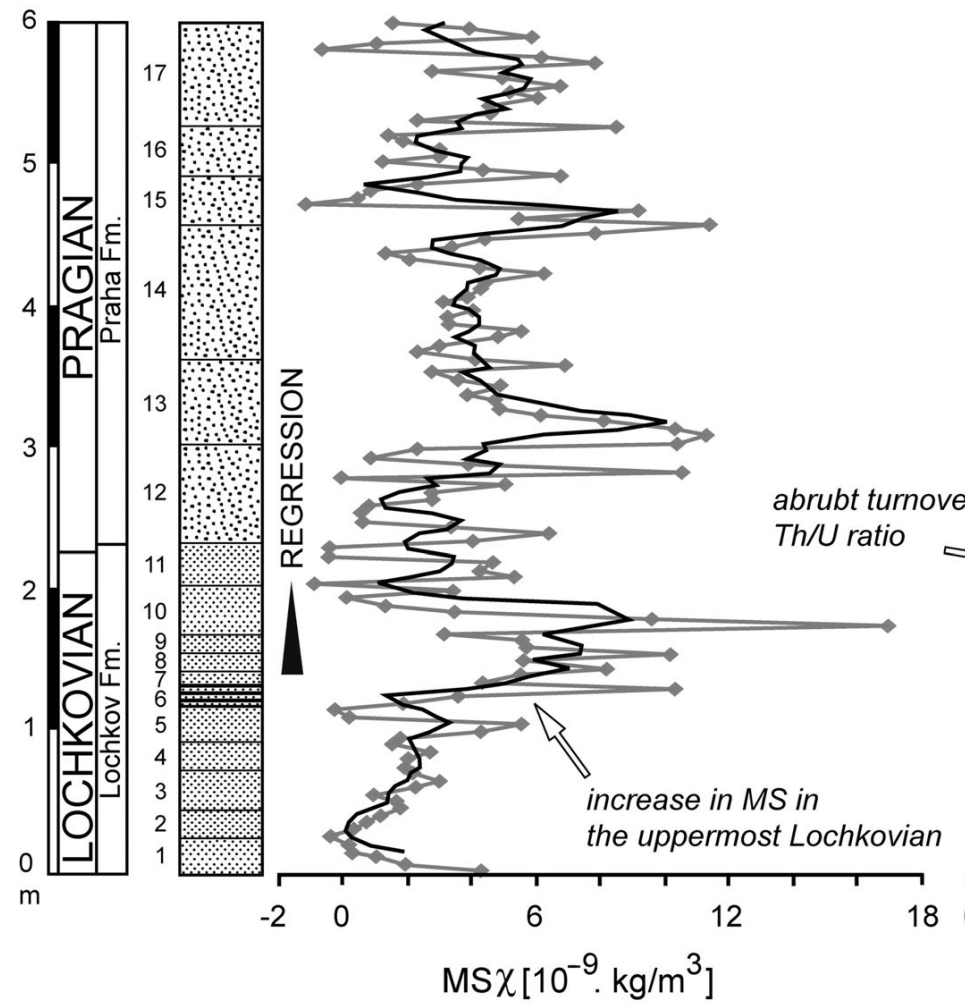

$\because \because \because$ coarse-grained bioclastic packstones/grainstones $\therefore \therefore$ (Slivenec Limestone)

fine-grained bioclastic wackestones/packstones (Kotýs Limestone)

Figure 2. Magnetosusceptibility and gamma-ray spectrometric logs of the Cikánka section (bed numbers after Chlupáč et al. 1985). Grey MS curve represents raw values; black curve has been smoothed using four-point running average method.

Hladil (2004) and Slavík et al. (2007), who reported the first occurrence of index taxa more definitively than in the previous studies.

\section{Study sections}

Lithology, sedimentology, biostratigraphy, and other aspects of the studied sections have been described in many previous papers (e.g., Chlupáč et al. 1985, Hladíková et al. 1997, Chlupáč 2000, Čáp et al. 2003, Vorel 2006, Slavík \& Hladil 2004, Slavík et al. 2007). Thus, only brief descriptions of the sampled intervals are given here.

The Cikánka section is situated in an abandoned quarry near Praha-Slivenec (N 50 0’ 5.168”, E 14 19 19'34.742"; Fig. 1 - locality A). The studied interval comprises beds 1-17 (thickness $6.05 \mathrm{~m}$; $122 \mathrm{MS}$ samples, 25 GRS measurements). It is characterized by predominance of massive, medium- to coarse-grained bioclastic packstones to grainstones. The lower part of the section (beds 1-11; Fig. 2) belongs to the uppermost part of the Lochkov Fm. (Kotýs Lm. - grey coloured medium-grained packstones/grainstones). The overlying beds of pink coarse-grained packstones/grainstones belong to the base of the Praha Fm. (Slivenec Lm.). The L-P boundary occurs in the upper part of bed 11 (Slavík et al. 2007).

The Homolka section is situated at Praha-Velká Chuchle (N 50 0’ 52.959”, E 14 22’ 20.822"; Fig. 1 - locality B). The studied interval comprises beds 1-37 (thickness $5.9 \mathrm{~m}$; 119 MS samples, 25 GRS measurements). The uppermost part of the Lochkov Fm. (beds 1-26; Fig. 3) consists of thin beds of fine- to medium-grained wackestones to packstones separated by thin shale intercalations. The overlying succession comprises fine-grained nodular mudstones (DvorceProkop Lm.) of the basal part of the Praha Fm. (beds 27-37; Fig. 3). The L-P boundary is defined by the first appearance of index conodont Eognathodus sulcatus "eosulcatus" in bed 12 (Slavík \& Hladil 2004). 


\section{Homolka Quarry at Praha-Velká Chuchle}

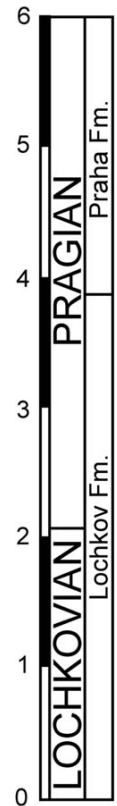

$\mathrm{m}$

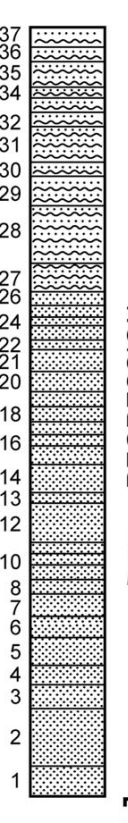

$-5$

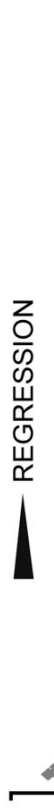

0
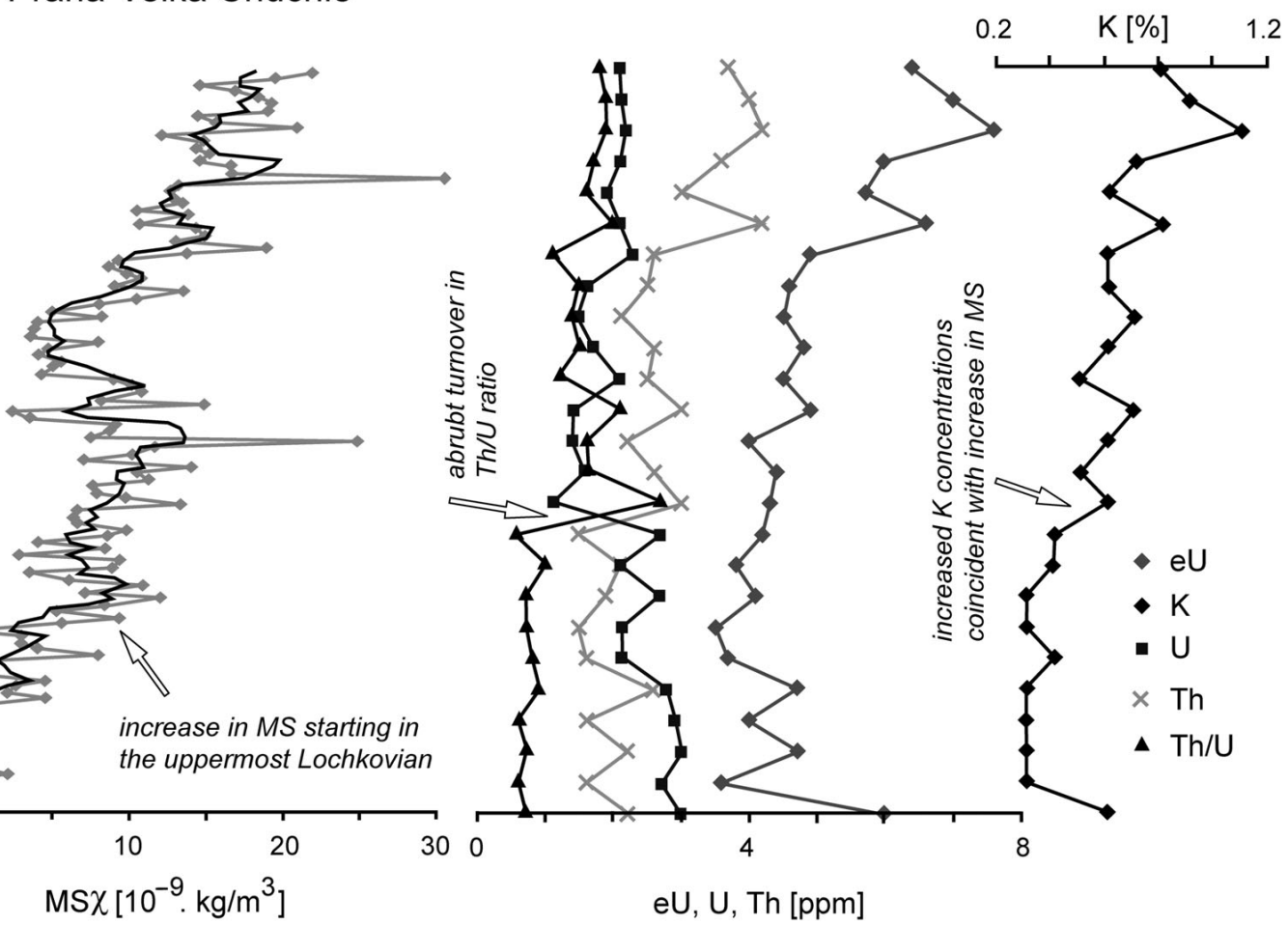

fine-grained bioclastic wackestones/packstones

Figure 3. Magnetosusceptibility and gamma-ray spectrometric logs of the Homolka section (bed numbers after Chlupáč et al. 1985). Grey MS curve represents raw values; black curve has been smoothed using four-point running average method.

The sampled interval at Černá rokle near Kosoř (N $49^{\circ}$ 59'22.932", E $14^{\circ} 20^{\prime} 17.405^{\prime \prime}$; Fig. 1 - locality C) is 6 m thick (121 MS samples, 25 GRS measurements). The uppermost part of the Lochkov Fm. is characterized by rhythmic alternation of fine-grained mudstones/wackestones and shales (Radotín Lm.; beds 60-86; Fig. 4). The base of the Praha Fm. is characterized by nodular mudstones (Dvorce-Prokop Lm.; bed. 87; Fig. 4). The L-P boundary is situated in bed 76 (Slavík et al. 2007).

\section{Methods}

Although all studied sections had been depicted in many papers they have been re-measured for our purposes to avoid any ambiguities. All three sections have been sampled and measured in thickness of approximately $6 \mathrm{~m}$. Sampling for the MS study was carried out in steps of $0.05 \mathrm{~m}$.

Small cubic or slice rock samples (20-50 g) were collected for study of stratigraphic variations in MS. Only fresh rock samples were taken (i.e. avoiding calcite veins, visible pyrite or limonite aggregates, spots with suspected dolomitization and shear-deformed parts of the rock).
Measurements were carried out in the Laboratory of Geological Processes (Institute of Geology, Academy of Sciences of the Czech Republic, v.v.i., Prague) on a Kappa Bridge KLY-2 (produced by Agico Ltd. Brno; for technical details, refer to www.agico.com). Raw MS data obtained from the instrument have been recalculated to mass-specific susceptibility $(\chi)$ expressed in $\mathrm{m}^{3} / \mathrm{kg} \times 10^{-9}$ (in descriptions of magnetic signals in the studied sections and the following discussion, this is reported simply as MS without units). Raw MS curves have been smoothed using four-point running average method in order to visualize better trends in MS (Figs 2-4).

Magnetic susceptibility is a material property related to amount of magnetizable minerals in a rock sample, which become magnetized in magnetic fields. Limestones have generally very low MS values as their rock-forming constituents (calcite and aragonite) have diamagnetic behaviour and very weak negative MS magnitudes. The enhanced MS signal in limestones is induced by presence of non-carbonate impurities including various ferromagnetic (sensu lato) minerals (magnetite, maghemite, hematite), and also weakly magnetic but much more abundant paramagnetic minerals (clay minerals, pyroxene, amphibole, biotite, chlorite, pyrite, chalcopyrite, a.o.). The basic con- 


\section{Černá rokle near Kosoř}

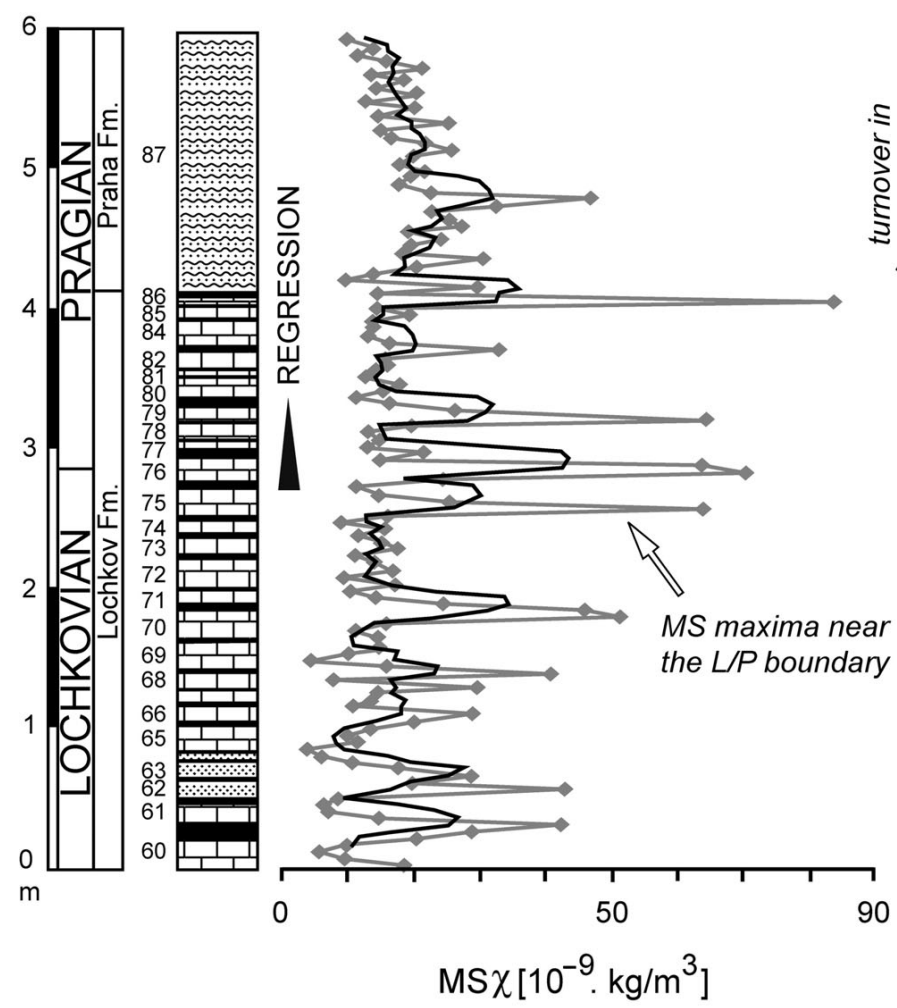

mudstones/wackestones (Radotín Limestone)

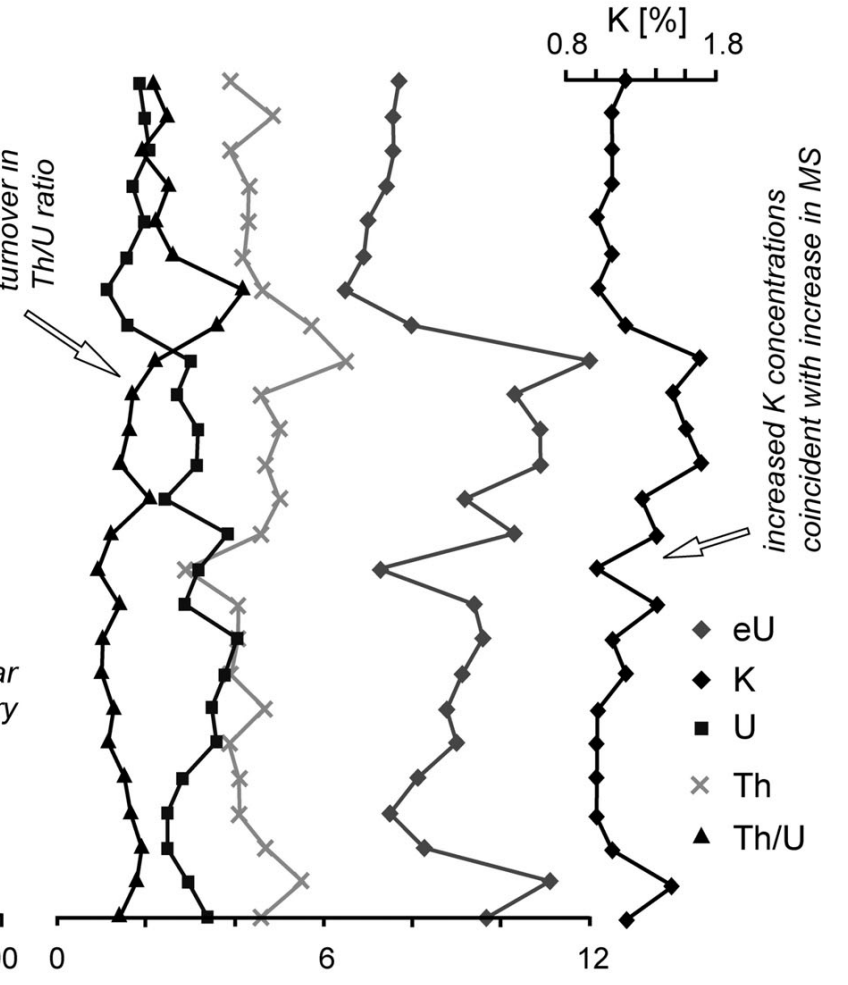

$\mathrm{eU}, \mathrm{U}, \mathrm{Th}[\mathrm{ppm}]$

nodular mudstones (Dvorce-Prokop Limestone)

calcareous shales

Figure 4. Magnetosusceptibility and gamma-ray spectrometric logs of the Černá rokle section (bed numbers after Chlupác et al. 1985). Grey MS curve represents raw values; black curve has been smoothed using four-point running average method.

cepts of MS stratigraphy described by Ellwood et al. (2000, 2001) are based on the assumption that the major part of the magnetic material is of terrigeneous origin (i.e., has been delivered to marine environments from land). According to this assumption, the supply with terrigeneous material is driven by fluctuations in sea-level, which control erosion in coastal areas and the delivery of weathering products to the sea. The maximum input of terrigeneous detritus should correspond to intensive erosion during the lowstand of sea-level and conversely, the delivery from land should be limited during highstands. Major events expressed in the MS are considered to be recognizable on both regional and global scales because of the synchronous variations in global erosion controlled by eustasy (Ellwood et al. 2000, 2001). However, there are many factors playing against this general assumption such as local synsedimentary tectonics or biotic events with enhanced carbonate productivity leading to lowering of the MS in major carbonate mass (Vacek et al. 2010) or eolian transport of non-carbonate material (Hladil 2002; Hladil et al. 2006, 2010a; Koptíková 2010b). Magnetite can also be of biogenic origin, produced by magnetotactic bacteria or algae. Many examples of this have been described in shallow-water conditions commonly associated with restricted circulation (for broad description and discussion on the primary and secondary magnetic minerals in carbonates see da Silva et al. 2009). However, some authors believe that biogenic magnetite contributes only very little to bulk MS as it does not respond to low inducing fields produced in measuring instruments (Ellwood et al. 2000).

The GRS measurements were performed using a field spectrometer Geofyzika-SatisGeo GS-512 with 0.25 m step at time of $240 \mathrm{~s}$. Numbers of detected radiogenic emissions have been automatically calculated to element concentrations of $\mathrm{K}(\%), \mathrm{U}(\mathrm{mg} / \mathrm{kg}=\mathrm{ppm})$ and $\mathrm{Th}(\mathrm{ppm})$. The total natural gamma-ray variation has been inferred from selected energy windows, all above $720 \mathrm{keV}$. This instrument also provides an additional automatically displayed 
parameter set to notional uranium equivalent contents (eU, $\mathrm{mg} / \mathrm{kg}$ or $\mathrm{ppm}$ ). However, this may be used only for rough estimates of total gamma activity of the analyzed rocks (for discussion see Geršl \& Hladil 2004).

Detected concentrations of K, U, and Th are mostly related to amount of feldspars, micas, and clay minerals, a.o. However, uranium is also known to be preferentially trapped in organic matter (e.g., Durrance 1986) and might be highly mobile during diagenetic processes. Therefore, its variations are mostly excluded from any environmental interpretations related to depositional processes. On the other hand, higher concentrations of $\mathrm{K}$ and Th should reflect increased amounts of non-carbonate mineral impurities in limestones that are caused by terrigeneous detrital influx.

\section{Main characteristics of the MS and GRS records}

The Cikánka section is characterized by relatively low MS values in the Lochkovian and Pragian parts of the section (see Table 1). A slightly upwards increasing trend can be seen (average magnitude for Lochkovian is 3.3, for Pragian 4.3). MS curve shows relatively high variations in both parts (standard deviations, SD, are 3.0 and 2.8). The uppermost Lochkovian is characterized by clearly upwards increasing trend in MS (see smoothed curve in Fig. 2), it is followed by a drop near the L-P boundary. The overlying Pragian sequence has also a progressive trend in MS (Fig. 2). Total gamma-activity of the measured rocks is also relatively low and tends to decrease upwards as along with $\mathrm{U}$ concentrations (Fig. 2). The Th/U ratio has distinctive progressive trend (its average value for Lochkovian is 0.7, for Pragian it is 2.6; see Fig. 2 and Table 1). Average magnitudes for $\mathrm{K}$ and $\mathrm{Th}$ remain relatively stable throughout whole section, concentrations of both elements show relatively low variations (see Table 1 for standard deviations). However, increased $\mathrm{K}$ and $\mathrm{Th}$ values, which correlate with increase in MS, can be seen near the L-P boundary (see Fig. 2). The eU is mostly related to variations in $\mathrm{U}$ content $\left(\mathrm{R}^{2}=0.9\right)$ and covariance with $\mathrm{K}$ and $\mathrm{Th}$ is very low $\left(\mathrm{R}^{2}=0.6\right.$ and 0.05$)$.

The MS curve of the Homolka section displays a pronounced increasing trend (see smoothed curve in Fig. 3). The average magnitude for the Lochkovian is 2.7, and 11.5 for the Pragian (there is relatively high variation of the MS values in both parts, SD are 3.9 and 5.3, respectively; see Table 1). An increasing trend is also observable for eU, $\mathrm{K}$, and Th. Coincident with this trend for eU, K and Th is an upward decreasing trend for U concentrations (see Fig. 3 and Table 1 for average concentrations and SD). Similar to the previous section, the $\mathrm{Th} / \mathrm{U}$ ratio clearly shows an upward increasing trend (average magnitude for Lochkovian is 0.7 , for Pragian it is 1.6). Trends in total gamma activity
(eU) can be mostly related to variations in $\mathrm{K}$ and $\mathrm{Th}\left(\mathrm{R}^{2}=\right.$ 0.84 and 0.88$)$. Conversely, the covariance between $\mathrm{eU}$ and $\mathrm{U}$ is very low $\left(\mathrm{R}^{2}=0.02\right)$.

In the Černá rokle section a slight increase in the MS is observable from the Lochkovian to the Pragian (average magnitudes are 18.0 and 21.9, MS in both parts shows high variations, $\mathrm{SD}$ are 12.2. and 14.1; Table 1). The $\mathrm{eU}$ and $\mathrm{U}$ curves show a slightly decreasing trend upward. The $\mathrm{K}$ and Th contents tend to slightly increase upwards. Concentrations of all three elements show only low or moderate variations in both distinguished segments (see Table 1 for average concentrations and SD). The highest concentrations of $\mathrm{K}$ and Th correspond to MS maxima near the base of Pragian (Fig. 4). The enhancement in Th concentrations is expressed also in the progressive trend in the $\mathrm{Th} / \mathrm{U}$ ratio (average value for Lochkovian is 1.4 , for Pragian it is 2.3 ). The eU magnitudes depend mostly on $\mathrm{K}\left(\mathrm{R}^{2}=0.85\right)$, while covariance with $\mathrm{U}$ and Th remains low $\left(\mathrm{R}^{2}=0.65\right.$ and 0.54$)$.

There is a remarkable difference in the trends of the GRS-detected elements at the transition from the uppermost part of the Lochkov Fm. (platy limestone/shales) to the basal Praha Fm. (nodular mudstones) between Homolka and Černá rokle sections. In the Homolka section $\mathrm{K}, \mathrm{U}$, and Th concentrations clearly show an increasing trend however, the Černá rokle section is characterized by the opposite tendency developed in similar facies (see Figs 3 and 4).

\section{Interpretation and discussion}

Numerous studies on the relationship between palaeoenvironmental changes and MS stratigraphic variations have been published in recent years. These interpretations come from the general assumption that there is a relationship between the amount of terrigeneous supply responsible for increased MS values and eustasy (Ellwood et al. 2000). However, there are also various factors which play against this generalization (e.g., Hladil et al. 2006, 2009; Da Silva et al. 2009; Vacek et al. 2010). The MS signal may be strongly modified by secondary processes such as magnetite neomorphism during diagenesis or secondary remagnetization (see e.g., Riquier et al. 2010), which certainly devalues interpretations that the primary MS record reflects depositional conditions and processes. Vacek et al. (2010) and Koptíková et al. (2010b), who studied analogous facies from this stratigraphic level in other sections in the Prague Synclinorium, ascribed the major effect on the MS signal to changing amounts of various paramagnetic minerals (pyroxenes, amphiboles, micas, chlorite, a.o.) whereas ferromagnetic components (mainly magnetite, hematite, and goethite) have been present only subordinately and have had only limited influence on the bulk MS. Therefore, we may assume that the MS record mainly reflects 
Table 1. Average magnitudes of the MS and GRS-based parameters in the studied sections, standard deviations for average values are given in brackets. Abbreviation: Lo-Lochkovian; $P g$ - Pragian.

\begin{tabular}{lcccccc}
\hline Sections/their segments & $\mathrm{MS}_{\chi}\left[10^{-9} \mathrm{~m}^{3} / \mathrm{kg}\right]$ & $\mathrm{eU}[\mathrm{ppm}]$ & $\mathrm{K}[\%]$ & $\mathrm{U}[\mathrm{ppm}]$ & $\mathrm{Th}[\mathrm{ppm}]$ & $\mathrm{Th} / \mathrm{U}$ \\
\hline Cikánka $\operatorname{Lo}(0.0-2.25 \mathrm{~m})$ & $3.3(3.0)$ & $4.5(1.1)$ & $0.4(0.1)$ & $1.7(0.9)$ & $1.7(0.4)$ & $0.7(0.5)$ \\
Cikánka $\operatorname{Pg}(2.25-6.05 \mathrm{~m})$ & $4.3(2.8)$ & $2.3(0.7)$ & $0.4(0.1)$ & $1.9(0.2)$ & $1.9(0.5)$ & $2.6(0.6)$ \\
Homolka $\operatorname{Lo}(0.0-2.15 \mathrm{~m})$ & $2.7(3.9)$ & $4.2(0.7)$ & $0.4(0.1)$ & $2.6(0.4)$ & $1.9(0.4)$ & $0.7(0.1)$ \\
Homolka $P g(2.15-5.9 \mathrm{~m})$ & $11.5(5.3)$ & $5.3(1.1)$ & $0.7(0.2)$ & $1.9(0.4)$ & $3.0(0.8)$ & $1.6(0.5)$ \\
Černá rokle $\operatorname{Lo}(0.0-2.8 \mathrm{~m})$ & $18.0(12.2)$ & $8.9(1.1)$ & $1.1(0.2)$ & $3.2(0.5)$ & $4.2(0.6)$ & $1.4(0.3)$ \\
Černá rokle $P g(2.8-6.0 \mathrm{~m})$ & $21.9(14.1)$ & $8.7(1.7)$ & $1.3(0.2)$ & $2.3(0.6)$ & $4.7(0.7)$ & $2.3(0.7)$ \\
\hline
\end{tabular}

primary conditions and can be used for further environmental interpretations.

There is a more or less distinctive progressive trend in the MS from Lochkovian to Pragian in all three studied sections (see Table 1). This trend is apparent in the Cikánka and Homolka sections (see smoothed curves in Figs 2 and 3). In the Černá rokle sections numerous MS peaks related to alternation of limestone and shale beds may cloak the overall trend (Fig. 4). As these MS peaks mostly correspond to limestone beds, this pattern is related to increased delivery of magnetic particles by calciturbidites to the carbonate slope environment with prevailing hemipelagic sedimentation (see Vacek et al. 2010).

A similar, slightly upward increasing trend holds for $\mathrm{K}$ and Th which also may reflect enhanced amounts of detrital material in Pragian parts of all sections. This increase starts near the base of Pragian in all sections even if it is still situated in the "Lochkovian" facies (see Figs 2-4). Similar patterns of MS and GRS stratigraphic variations at the L-P boundary have been also described from other sections in this area (e.g., Požáry Quarry near Praha-Reporyje in the NW part of the Prague Synclinorium; Koptíková et al. 2010a, b).

If we apply the basic concept of MS stratigraphy (Ellwood et al. 2000, 2001) to our sections, we could conclude that the increased amount of non-carbonate impurities at the L-P transition reflects a regressive event. This is in accordance with the traditional idea based on faunal changes that the L-P boundary event is regressive (Chlupác \& Kukal 1988). Regressive conditions also may be supported by the facies changes in the shallow-water settings (e.g., Cikánka section) where grey-coloured Kotýs Lm. in the uppermost Lochkovian (bioclastic wackestones/packstones) is replaced in the lowermost Pragian by pink-coloured Slivenec Lm. (coarse-grained bioclastic grainstones; Čáp et al. 2003, Vorel 2006). On the other hand, facies changes at the transition from the Lochkovian to Pragian in the carbonate slope environment rather suggest an opposite trend - nodular mudstones (DvorceProkop Lm.) at the base of the Praha Fm. are considered deposits of highstand conditions (Vorel 2006).

The L-P transition in all our sections as well as in other sections described in literature (e.g., Slavík et al. 2000;
Hladil et al. 2008; Koptíková et al. 2010 a, b) is characterized by an abrupt turnover in $\mathrm{Th} / \mathrm{U}$ ratio. The Pragian magnitudes are usually 2-4x higher than Lochkovian values. According to Ruffell \& Worden (2000) the Th/U ratio may have palaeoclimatic implications. It is known that $U$ and $\mathrm{K}$ are more soluble than Th. Content of Th increases with weathering on land during hot and humid climatic phases. Thus, low magnitudes of $\mathrm{Th} / \mathrm{U}$ should correspond to colder climate and higher values to warm climatic conditions, with enhanced amounts of Th delivered from land to sea. Applying these premises to our studied sections, we interpret the abrupt change in $\mathrm{Th} / \mathrm{U}$ at the L-P boundary as a result of warming (see also Hladil et al. 2008, Vacek 2010 or Koptíková et al. 2010b). It is notable that this Th/U trend has been recorded across the Prague Synclinorium in various facies. This presumed palaeoclimatic event coincides with the facies change at the base of the Praha Fm. (see above). In deeper-water environments, distal calciturbidites with shales are replaced by hemipelagic mudstones. This change has been explained as a result of se-level rise (Vorel 2006). This interpretation might be in accordance with presumed palaeoclimate warming which caused glaciers melting and sea-level rise. This might be expressed in enhanced carbonate productivity during transgression and highstand (highstand shedding effect of Schlager et al. 1994) and disappearance of shales with lower carbonate content (Vacek 2010). This interpretation is supported by the progressive trend in $\mathrm{CaCO}_{3}$ content from the Lochkovian to Pragian described by Koptíková et al. (2010b). However, it contradicts the shallowing-trend observable in shallow-water facies (see above in the text). Thus, these general assumptions would lead to a completely opposite interpretation of the facies change at the L-P boundary in different settings. However, these changes need not be a result of a significant sea-level fluctuation, but rather result from a climatic event. As described by Vacek et al. (2010), synsedimentary tectonics also might have caused short-term facies changes, which might be confused with effects of minor eustatic sea-level changes. The widespread distribution of shallow-water facies (including reef facies in the Koněprusy area, SW part of the Prague Synclinorium) in the lower part of the Praha Fm. also suggests a regressive trend during this time interval. 
However, the regression might be modified locally by synsedimentary uplift, with eustasy playing only a minor role. The synsedimentary uplift in this time interval is best documented in the Koněprusy area (SW part of the Prague Synclinorium), where it is expressed in a stratigraphic gap in the upper Lochkovian (Chlupáč 2003).

Originally defined on paleontological and lithological data, the regressive event at the L-P boundary has been analysed by various other methods, e. $g$. by isotopic studies. Hladíková et al. (1997) described a gradual increasing trend in $\delta^{13} \mathrm{C}$ both in the Lochkovian and Pragian parts of the Homolka section. They explained this increase as a result of enhanced bioproductivity during the LochovianPragian regressive phase or increased burial of organic matter. Buggisch \& Mann (2004) provided evidence for a sharp increase in $\delta^{13} \mathrm{C}$ at the L-P boundary in other sections from the Prague Synclinorium (including the Černá rokle section) as well as from other regions of Europe (Carnic Alps and Cantabrian Mountains). Buggisch \& Mann (2004) also ascribed this increase to the effects of a drop in sea-level during the Lochkovian-Pragian interval. These effects have been also reported from other parts of the world as well, e.g. central Asia (Koren et al. 2007), Northern America (Johnson \& Murphy 1984, Johnson et al. 1985), Australia (Talent \& Yolkin 1987) or Northern Africa (Chlupáč et al. 1988, Lubeseder 2008) indicating that the event is probably global in nature. Results of studies on carbon and oxygen isotopes published by Buggisch \& Mann (2004) and Saltzman (2005) suggest a pronounced global event in palaeooceanographic conditions related to climate warming. While the Silurian to Lochkovian period has been characterized by cool-water conditions, the succeeding Pragian to Givetian interval was distinguished by higher temperatures of the oceans. However, Joachimski et al. (2009) concluded from oxygen isotopes from conodont apatite that Lochkovian was a period of warm tropical climate, which was followed by cooling in Pragian characterized by intermediate temperatures.

As described above our data and interpretations contribute to the palaeonvironmental image of this time interval in the Devonian type area. Our results are consistent with various data published previously, but they are in contradiction with other theories such as that of Joachimski et al. (2009).

\section{Conclusions}

The MS and GRS stratigraphic records of three L-P boundary sections representing different depositional conditions have been evaluated. The boundary interval is characterized by facies change in all studied sections. All sections display an increase in MS that coincides with increased $\mathrm{K}$ and Th concentrations from uppermost Lochkovian to Pragian. This may reflect increased delivery of terrigeneous material as a result of a regressive trend (e.g., the previously defined Lochkovian-Pragian boundary event). Another prominent characteristic in these sections is a turnover in the $\mathrm{Th} / \mathrm{U}$ ratio with the Pragian magnitudes $2-4 \times$ higher than the Lochkovian values. Based on combined physical stratigraphic and sedimentological approach, the previously reported regressive event during this time interval is ascribed to climatic warming accompanied by enhanced carbonate productivity (as documented by the increasing amount of $\mathrm{CaCO}_{3}$ in limestones in the lower part of the Praha Fm. and the isotopic data reported in the literature). Eustatic sea-level changes probably played only a subordinate role in the L-P boundary event and local synsedimentary uplift such as that documented in various parts of the Prague Synclinorium may enhance or mask this eustatic signal.

\section{Acknowledgements}

Author is grateful to L. Koptíková (Geological Institute, AV CR, v.v.i.) for her help with the MS measurements. J.R. Ebert and B.B. Ellwood are highly acknowledged for their valuable comments and suggestions, which helped improve the original manuscript. This research was supported by projects GAAV IAAX00130702, GACR 210/10/2351, and MSM 0021620855. This paper is contribution to IGCP 580 .

\section{References}

BÁBeK, O., PŘIKRYl, T. \& HLADIL, J. 2007. Progressive drowning of carbonate platform in the Moravo-Silesian Basin (Czech Republic) before the Frasnian/Famenian event: facies, compositional variations and gamma-ray spectrometry. Facies 53, 293-316. DOI 10.1007/s10347-006-0095-8

Boulvain, F., da Silva, A.C., Mabille, C., Hladil, J., Geršl, M., KoptíkovÁ, L. \& Schnabl, P. 2010. Magnetic susceptibility correlation of km-thick Eifelian-Frasnian sections (Ardennes and Moravia). Geologica Belgica 13(4), 309-318.

Buggisch, W. \& MAnN, U. 2004. Carbon isotope stratigraphy of Lochkovian to Eifelian limestones from the Devonian of central and southern Europe. International Journal of Earth Sciences 93, 521-541.

ČÁP, P., VACEK, F. \& Vorel, T. 2003. Microfacies analysis of Silurian and Devonian type sections (Barrandian, Czech Republic). Czech Geological Survey, Special Papers 15, 1-40.

Carls, P., Slavík, L. \& Valenzuela-Ríos, J.I. 2008. Comments on the GSSP for the basal Emsian stage boundary: the need for its redefinition. Bulletin of Geosciences 83(4), 383-390. DOI 10.3140/bull.geosci.2008.04.383

CHLUPÁČ, I. 1953. Stratigrafická studie o hraničních vrstvách mezi silurem a devonem ve středních Čechách (Stratigraphical Investigation of the Border Strata of the Silurian and the Devonian in Central Bohemia - English summary). Sborník Ústředního ústavu geologického, Oddíl geologický 20, 277-347.

ChLUPÁč, I. 1957. Faciální vývoj a biostratigrafie středočeského spodního devonu (Facial Development and Biostratigraphy of the Lower Devonian of Central Bohemia - English summary). 
Sborník Ústředního ústavu geologického, Oddíl geologický 23, 369-485.

CHLupéč, I. 1981. Stratigraphic terminology of the Devonian in Central Bohemia (Barrandian area, Czechoslovakia). Věstník Ústředního ústavu geologického 56(5), 263-270.

Chlupéč, I. 1982. The Bohemian Lower Devonian stages. Courier Forschungsinstitut Senckenberg 55, 345-400.

Chlupéč, I. 2000. The global stratotype section and point of the lower Pragian boundary. Courier Forschungsinstitut Senckenberg 225, 9-15.

Chlupáč, I. 2003. Comments on facies development and stratigraphy of the Devonian, Barrandian area, Czech Republic. Bulletin of Geosciences 78(4), 299-312.

Chlupáč, I., Havlíček, V., KŘíž, J., Kukal, Z. \& Štorch, P. 1998. Palaeozoic of the Barrandian (Cambrian to Devonian). 183 pp. Czech Geological Survey, Prague.

Chlupáč, I. \& KuKal, Z. 1988. Possible global events and the stratigraphy of the Palaeozoic of the Barrandian (CambrianMiddle Devonian, Czechoslovakia). Sborník geologických věd, Geologie 43, 83-146.

Chlupáč, I., Lukeš, P., Paris, F. \& Schönlaub, H.P. 1985. The Lochkovian-Pragian boundary in the Lower Devonian of the Barrandian area (Czechoslovakia). Jahrbuch der Geologischen Bundesanstalt 128, 9-41.

ChlupÁč, I. \& Oliver, JR., W.A. 1989. Decision on the Lochkovian-Pragian boundary stratotype (Lower Devonian). Episodes 12(2), 109-113.

Crick, R.E., Ellwood, B.B., El Hassani, A., Feist, R. \& Hladil, J. 1997. Magnetosusceptibility event and cyclostratigraphy (MSEC) of the Eifelian-Givetian GSSP and associated boundary sequences in north Africa and Europe. Episodes 20(3), $167-175$.

Crick, R.E., Ellwood, B.B., Hladil, J., El Hassani, A., Hrouda, F. \& CHLUPÁČ, I. 2001. Magnetostratigraphy susceptibility of the Př́idolian-Lochkovian (Silurian-Devonian) GSSP (Klonk, Czech Republic) and a coeval sequence in Anti-Atlas Morocco. Palaeogeography, Palaeoclimatology, Palaeoecology 167, 73-100. DOI 10.1016/S0031-0182(00)00233-9

Da Silva, A.C., Mabille, C. \& Boulvain, F. 2009. Influence of sedimentary setting on the use of magnetic susceptibility: examples from Devonian of Belgium. Sedimentology 56, 1292-1306. DOI 10.1111/j.1365-3091.2008.01034.x

DURRANCE, E.M. 1986. Radioactivity in geology: principles and applications. 441 pp. Ellis Horwood, Chichester.

Ellwood, B.B., Crick, R.E., El Hassani, A., Benoist, S.L. \& Young, R.H. 2000. Magnetosusceptibility event and cyclostratigraphy method applied to marine rocks: Detrital input versus carbonate productivity. Geology 28(12), 1135-1138. DOI 10.1130/0091-7613(2000)28<1135:MEACMA>2.0.CO;2

Ellwood, B.B., Crick, R.E., García-Alcade Fernandez, J.L., Soto, F.M., Truyóls-Massoni, M., El Hassani, A. \& Kovas, E.J. 2001. Global correlation using magnetic susceptibility data from Lower Devonian rocks. Geology 29(7), 583-586. DOI 10.1130/0091-7613(2001)029<0583:GCUMSD>2.0.CO;2

Ellwood, B.B., García-Alcade Fernandez, J.L., El Hassani, A., Hladil, J., Soto, F., Truyóls-Massoni, M., Wedigge, K. \& KoptíkovÁ, L. 2006. Stratigraphy of the Middle Devonian boundary: Formal definition of the susceptibility magnetostratotype in Germany with comparisons to sections in the Czech Republic, Morocco and Spain. Tectonophysics 418, 31-49. DOI 10.1016/j.tecto.2005.12.012

GERŠL, M. \& HLADIL, J. 2004. Gamma-ray and magnetic suscepti- bility correlation across a Frasnian carbonate platform and the search for "punctata" equivalents in stromatoporoid-coral limestone facies of Moravia. Geological Quarterly 48(3), 283-292.

Gessa, S. \& Lécuyer, C. 1998. Evolutionary dynamics of Pragian Dacryoconarida (Lower Devonian, Tentaculitoidea): evidence from palaeontological data and $\delta^{13} \mathrm{C}$ of marine carbonates from Czech Republic. Palaeogeography, Palaeoclimatology, Palaeoecology 138, 69-83.

DOI 10.1016/S0031-0182(97)00120-X

Hajná, J., Žák, J., Kachlík, V. \& Chadima, M. 2010. Subduction-driven shortening and differential exhumation in a Cadomian accretionary wedge: The Teplá-Barrandian unit, Bohemian Massif. Precambrian Research 176, 27-45.

HLADIL, J. 2002. Geophysical records of dispersed weathering products on the Frasnian carbonate platform and early Famennian ramps in Moravia, Czech Republic: proxies for eustasy and palaeoclimate. Palaeogeography, Palaeoclimatology, Palaeoecology 181, 213-250.

DOI 10.1016/S0031-0182(01)00480-1

Hladil, J., Bosák, P., Jansa, L.F., TěŽKÝ, A., Helesicová, K., Hrubanová, J., Pruner, P., Krưta, T., ŠPaČek, P. \& Chadima, M. 2000. Frasnian eustatic cycles viewed with gamma spectrometric and magnetosusceptibility stratigraphy tools (Moravia): Six major floodings on cratonized basement. Subcommission on Devonian Stratigraphy, Newsletter 17, 48-52.

Hladil, J., Bosák, P., Slavík, L., Carew, J.L., Mylroie, J.E. \& GERŠL, M. 2003a. A pragmatic test of early origin and fixation of gamma-ray spectrometric (U, Th) and magneto-susceptibility $(\mathrm{Fe})$ patterns related to sedimentary cycle boundaries in pure platform limestones. Carbonates and Evaporites 18 (2), 89-107. DOI 10.1007/BF03176231

Hladil, J., Bosák, P., Slavík, L., Carew, J.L., Mylroie, J.E. \& GERŠL, M. 2003b. Early diagenetic origin and persistence of gamma-ray and magnetosusceptibility patterns in platform carbonates: comparison of Devonian and Quaternary sections. Physics and Chemistry of the Earth 28, 719-727.

Hladil, J., Čejchan, P., BábeK, O., Koptíková, L., Navrátil, T. \& KubínovÁ, P. 2010a. Dust - a geology-orientated attempt to reappraise the natural components, amounts, inputs to sediment, and importance for correlation purposes. Geologica Belgica 13(4), 367-384.

Hladil, J., Geršl, M., Strnad, L., Frána, J., Langrová, A. \& SPIŠIAK, J. 2006. Stratigraphic variations of complex impurities in platform limestones and possible significance of atmospheric dust: a study with emphasis on gamma-ray spectrometry and magnetic susceptibility outcrop logging (EifelianFrasnian, Moravia, Czech Republic). International Journal of Earth Sciences 95(4), 703-723.

DOI 10.1007/s00531-005-0052-8

Hladil, J., Koptíková, L., Galle, A., Sedláček, V., Pruner, P., Schnabl, P., Langrová, A., Bábek, O., Frána, J., Hladíková, J., OtAva, J. \& GerŠL, M. 2009. Early Middle Frasnian platform reef strata in the Moravian Karst interpreted as recording the atmospheric dust changes: the key to understanding perturbations in the punctata conodont zone. Bulletin of Geosciences 84(1), 75-106. DOI 10.3140/bull.geosci.1113

Hladil, J., Slavík, L., Schnabl, P., Koptíková, L., Frána, J., VACEK, F. \& BÁBEK, O. 2008. The gross environmental phenomenon of the classical Pragian stage ("hot lowstand"). $33^{\text {rd }}$ International Geological Congress, IUGS, Oslo, Abstract CD-ROM, HPF-01, 1343454. 
Hladil, J., Vondra, M., Čejchan, P., Vich, R., Koptíková, L. \& SLAVí, L. 2010b. The dynamic time-warping approach to comparison of magnetic-susceptibility logs and application to Lower Devonian calciturbidites (Prague Synform, Bohemian Massif). Geologica Belgica 13(4), 385-406.

Hladíková, J., Hladil, J. \& Kř́íbeK, B. 1997. Carbon and oxygen isotope record across Pridoli to Givetian stage boundaries in the Barrandian basin (Czech Republic). Palaeogeography, Palaeoclimatology, Palaeoecology 132, 225-241. DOI 10.1016/S0031-0182(97)00062-X

Joachimski, M.M., Breisig, S., Buggisch, W., Talent, J.A., Mawson, R., Gereke, M., Morrow, J.R., Day, J. \& Weddige, K. 2009. Devonian climate and reef evolution: Insight from oxygen isotopes in apatite. Earth and Planetary Science Letters 284, 599-609. DOI 10.1016/j.eps1.2009.05.028

Johnson, J.G., Klapper, G. \& SAndBerg, C.A. 1985. Devonian eustatic fluctuations in Euramerica. Geological Society of America Bulletin 96, 567-587. DOI 10.1130/0016-7606(1985)96<567:DEFIE >2.0.CO;2

Johnson, J.G. \& Murphy, M.A. 1984. Time-rock model for Siluro-Devonian continental shelf, western United States. Bulletin of the Geological Society of America 95, 1349-1359. DOI 10.1130/0016-7606(1984)95<1349:TMFSCS>2.0.CO;2

KoptíkovÁ, L. 2010. Precise position of the Basal Choteč event and evolution of sedimentary environment close above the Lower-Middle Devonian boundary: magnetic susceptibility, gamma-ray spectrometric, lithological and geochemical record in Prague Synform (Czech Republic). Palaeogeography, Palaeoclimatology, Palaeoecology.

DOI 10.1016/j.palaeo.2010.10.011

Koptíková, L., Bábek, O., Hladil, J., Kalvoda, J. \& Slavík, L. 2010a. Stratigraphic significance and resolution of spectral reflectance logs in Lower Devonian carbonates of the Barrandian area, Czech Republic; a correlation with magnetic susceptibility and gamma-ray logs. Sedimentary Geology 225, 83-98. DOI 10.1016/j.sedgeo.2010.01.004

Koptíková, L., Hladil, J., Slavík, L., Čejchan, P. \& Bábek, O. 2010b. Fine-grained non-carbonate particles embedded in neritic to pelagic limestones (Lochkovian to Emsian, Prague Synform, Czech Republic): Composition, provenance and links to magnetic susceptibility and gamma-ray logs. Geologica Belgica 13(4), 407-430.

Koren', T.N., Kim, A.I. \& Walliser, O.H. 2007. Contribution to the biostratigraphy around the Lochkovian-Pragian boundary in Central Asia (graptolites, tentaculites, conodonts). Senckenbergiana lethaea 87(2), 187-219.

KRs, M. \& Pruner, P. 1995. Palaeomagnetism and palaeogeography of the Variscan formations of the Bohemian Massif, comparison with other European regions. Journal of Czech Geological Society 40(1-2), 3-46.

Krs, M., Pruner, P. \& Man, O. 2001. Tectonic and paleogeographic interpretation of the paleomagnetism of Variscan and pre-Variscan formations of the Bohemian Massif, with special reference to the Barrandian terrane. Tectonophysics 332, 93-114. DOI 10.1016/S0040-1951(00)00251-1

LuBESEDER, S. 2008. Palaeozoic low-oxygen, high-latitude carbonates: Silurian and Lower Devonian nautiloid and scyphocrinoid limestones of the Anti-Atlas (Morocco). Palaeogeography, Palaeoclimatology, Palaeoecology 264, 195-209. DOI 10.1016/j.palaeo.2008.04.007

Melichar, R. 2004. Tectonics of the Prague Synform: a hundred years of scientific discussion. Krystalinikum 30, 167-187.
Melichar, R. \& Hladil, J. 1999. Resurrection of the Barrandian nappe structures, central Bohemia. Geolines 8, 48-50.

PatočKa, F., Pruner, P. \& Štorch, P. 2003. Palaeomagnetism and geochemistry of Early Palaeozoic rocks of the Barrandian (Teplá-Barrandian Unit, Bohemian Massif): palaeotectonic implications. Physics and Chemistry of the Earth 28, 735-749.

Riquier, L., Averbuch, O., Devleeschouver, X. \& TribovilLARD, N. 2010. Diagenetic versus detrital origin of the magnetic susceptibility variations in some carbonate FrasnianFamennian boundary sections from Northern Africa and Western Europe: implications for paleoenvironmental reconstructions. International Journal of Earth Sciences 99, Supplement 1, S57-S73. DOI 10.1007/s00531-009-0492-7

RufFell, A. \& Worden, R. 2000. Paleoclimatic analysis using spectral gamma-ray data from the Aptian (Cretaceous) of southern England and southern France. Palaeogeography, Palaeoclimatology, Palaeoecology 155, 265-283.

DOI 10.1016/S0031-0182(99)00119-4

SAltzman, M.R. 2005. Phosphorus, nitrogen, and the redox evolution of the Paleozoic oceans. Geology 33(7), 573-576. DOI $10.1130 / \mathrm{G} 21535.1$

Schlager, W., Reijmer, J.J.G. \& Droxler, A. 1994. Highstand shedding of carbonate platforms. Journal of Sedimentary Research B64(3), 270-281.

Slavík, L. \& HLAdIL, J. 2004. Lochkovian/Pragian GSSP revisited: Evidence about conodont taxa and their stratigraphic distribution. Newsletter on Stratigraphy 40(3), 137-153.

Slavík, L., Hladil, J., BlažeK, R. \& Krưta, M. 2000. Anatomy of the Pragian stratigraphic column: gamma spectrometric record throughout complete $170-\mathrm{m}$ thick Pragian section in calciturbidite/hemipelagite facies (Prague, section "Under Barrandov Bridge"). Subcommission on Devonian Stratigraphy Newsletter 17, 46-47.

Slavík, L., Valenzuela-Ríos, J.I., Hladil, J. \& Carls, P. 2007. Early Pragian conodont-based correlations between the Barrandian area and the Spanish Central Pyrenees. Geological Journal 42, 499-512. DOI 10.1002/gj.1087

TAlent, J.A. \& YolKIn, E.A. 1987. Transgression-regression patterns for the Devonian of Australia and southern West Siberia. Courier Forschungsinstitut Senckenberg 92, 235-249.

VACEK, F. 2007. Carbonate microfacies and depositional environments of the Silurian-Devonian boundary strata in the Barrandian area (Czech Republic). Geologica Carpathica 58(6), 497-510.

VACEK, F. 2010. Evolution of the depositional environment at the Lochkovian-Pragian boundary in the Prague Basin based on gamma-ray spectrometry (in Czech). Geoscience Research Reports for 2009, 63-65.

VACEK, F., Hladil, J. \& Schnabl, P. 2010. Stratigraphic correlation potential of magnetic susceptibility and gamma-ray spectrometric variations in calciturbiditic facies mosaics (Silurian-Devonian boundary, Barrandian area, Czech Republic). Geologica Carpathica 61(4), 257-272. DOI 10.2478/v10096-010-0015-2

VELEBILOVÁ, L. \& ŠARF, P. 1996. Application of microfacies analysis in the Lower Devonian of the Barrandian, central Bohemia. Journal of the Czech Geological Society 41, 105-115.

VOREL, T. 2006. Sedimentology of the Lochkovian-Pragian boundary interval in the Lower Devonian of the Barrandian area. Acta Universitatis Carolinae, Geologica 47(1-4), 193-203.

Weddige, K. 1987. The Lower Pragian boundary (Lower Devonian) based on the conodont species Eognathodus sulcatus. Senckenbergiana lethaea 67, 479-487. 